\title{
ANALYSIS OF SUBMISSION PROCEDURE AND WORKING ADVANCES ACCOUNTABILITY IN ATTEMPT TO IMPROVE INTERNAL CONTROL: A STUDY ON PUBLIC SERVICE COMPANY OF JASA TIRTA I MALANG HEAD OFFICE
}

\author{
Dzulkirom AR M. ${ }^{*}$, Nurmalasari G.A. \\ Faculty of Administrative Sciences, University of Brawijaya, Malang, Indonesia \\ *E-mail: dzulkirom.m@ub.ac.id
}

\begin{abstract}
This study aims to find out the submission procedure and Working Advances accountability, analyze the submission procedure and Working Advances accountability, and improve internal control of the submission procedure and Working Advances accountability. The type of research used in this study is descriptive with the qualitative approach. The focus in this research is the submission procedure and Working Advances accountability and the improvement of internal control in the submission procedure and Working Advances accountability. The obtained data sources were from primary and secondary data. The data were collected by conducting interviews with the Head of Budget Division and Staff of Budget as primary data and documentation as secondary data. The data analysis used in this study was descriptive analysis. The results showed that the entire procedures had run quite well and correlated to the existing corporate regulations. However, there was still a slight deficiency that was the processing time of Working Advances payment approval carried out by the Board of Directors because these parties were often conducting External Service (DL). Other Insignificant deficiencies were the accumulation of documents of Working Advances accountability performed by the Management Accounting Staff due to in unison with other works.
\end{abstract}

\section{KEY WORDS}

Procedure, submission, accountability, working advances.

Regarding the Letter of the Ministry of State-owned Enterprise (BUMN) No. S163/MBU/03/2017 dated March 10, 2017, concerning the submission of the Standard Draft of the BUMN Tbk Non-Banking Sector Articles of Association, the Ministry of BUMN delivered the Articles of Association Standardization Program (AD) of BUMN. So far, BUMN has Articles of Association that works well but it does not have any standard. There are still many state-owned enterprises which describe unclear procedures. Therefore, there needs to be a submission of the Articles of Association Standardization Program (AD) of BUMN (BUMN, 2017).

The budget itself is a quantitative statement in the monetary unit about a program of activities as well as functioning as a tool to coordinate the implementation of the plan. (Samryn 2012: 202). However, most people think that businesses or small companies do not need to use the budget. Most people argue that this budget is only for large companies. For this reason, large and small companies should design a budgeting plan. This budget is necessary for planning and controlling. Moreover, the budget has other uses like for job evaluation and to direct the behavior of managers and employees. The budget is indeed needed by State-Owned Enterprise (BUMN) to accelerate and to create efficiency on the achievement of the task. When a State-Owned Enterprise (BUMN) does not have an Articles of Association (AD), it will have an impact on the inefficient implementation of the tasks. It surely can be detrimental to the Country considering that some or all of the shareholders of a State-Owned Enterprise (BUMN) are the State itself. In achieving an efficient task and increasing internal control of the company, it is essential to apply Working Advances related to the corporate budget. The submission procedure and Working Advances accountability is used to overcome errors in the process, recording, and payment of Working Advances regarding the Corporate Work Plan and Budget (RKAP). 
BUMN's budget is regulated in the Decree of the Minister of BUMN No. Kep101/MBU/2002 concerning the Design of Work Plan and Corporate Budget of the StateOwned Enterprise that explains, "the Board of Directors is obliged to prepare a Work Plan and Corporate Budget which is a description of the Long-Term Business Plan of the StateOwned Enterprise." As referred to in article (3), the Corporate Work Plan and Budget (RKAP) shall at least contain (a) the Corporate Work Plan; (b) Corporate Budget; (c) Corporate Basic Financial Projection; (d) Subsidiary Basic Financial Projection and; (e) Other matters that require a decision of the General Meeting of Shareholders (GMS). The definition of Procurement Budget for BUMN is in the appendix of the Minister of BUMN Decree Number Kep-101/MBU/2002 concerning the Design of Work Plan and Corporate Budget of StateOwned Enterprises in the part of Corporate Budget. The Corporate budget itself is the elaboration of the business activity program in monetary unit based on receipt/expenditure in cash from the activity program to implement Government/Shareholder's Assignments and commercial activities. While the Procurement Budget is reportedly in detail according to raw materials, auxiliary materials, spare parts, other materials and traded goods. This Procurement Budget also includes activities budget designed for rent and sub-contract as well as being presented in the form of used currency unit.

Working Advances used for Routine Costs and Operational \& Maintenance Costs at public service company (Perum) Jasa Tirta I, make these Working Advances grouped in the Procurement Budget. However, Perum Jasa Tirta I is a company engaged in the field of a surveyor, then the Procurement Budget is replaced by the Operating Budget presented in detail based on the type of costs and the business area and strategic business units. Working Advances shall be in good form of budgeting for a company to avoid unnecessary matter. Hence, the corporate operational activities will run well. It requires good internal control to monitor all corporate operational activities.

Internal control is a set of policies and procedures to protect the corporate assets from any misuse. It is also to ensure the availability of accurate information, and all provisions, as well as to verify the management's policies adhered to or implemented accurately by all employees (Hery, 2007). Every company needs this internal control, especially for StateOwned Enterprises (BUMN). It is helpful to avoid internal problems that cause ineffective operational activities. If the State-Owned Enterprise does not have good internal control, it may harm the Country.

Internal control of BUMN regulated in Article 22 of the Minister of BUMN Decree No. Kep-117/M-MBU/2002 concerning Good Governance Implementation states that "the Board of Directors shall establish an effective internal control system to secure investment and asset of BUMN." Based on the elaboration of this regulation, it is concluded that BUMN in its implementation of internal control uses the COSO framework (Committee of Sponsoring Treadway Organization Commission). The existence of the internal control system element contained in the Decree of the Minister of BUMN is a real proof; it is not much different from the components of the internal control system within the framework of COSO (Committee of Sponsoring Treadway Organization Commission). COSO (Committee of Sponsoring Treadway Organization Commission) itself is an initiative from the private sector formed in 1985. The principal purpose of COSO (Committee of Sponsoring Treadway Organization Commission) is to recognize the factors that cause fraudulent financial statements and to offer suggestions to overcome the issue.

Perum Jasa Tirta $I$ is one of the State-Owned Enterprises (SOEs) operating in the field of water management and water resources as well as irrigation infrastructure in River Basin (WS) Brantas, WS Bengawan Solo, WS Jeratun Seluna, WS Serayu Bogowonto and WS Toba Asahan. The extent of the working area of Perum Jasa Tirta I in water management, water sources, and irrigation infrastructure are merely not far from the excellent financial management procedures. Perum Jasa Tirta I certainly has management tasks that require a lot of funds. Hence, it needs preparation for the Corporate Work Plan and Budget (RKAP) related to the Letter of the Ministry of BUMN No. S-163/MBU/03/2017 dated March 10, 2017, concerning the submission of the Standard Draft of the BUMN's Articles of Association, as well as the procedures for implementation and Working Advances accountability that will 
considerably affect the amount of burden of Perum Jasa Tirta I. Moreover, when observing in the field, the researchers saw that there were several problems in implementing the procedures like the delay in voucher approval process of Working Advances payment performed by Director II and the accumulation of documents undertaken by the Management Accounting Staff. With these problems, the researcher is interested in conducting a study on the submission procedure and Working Advances accountability at Perum Jasa Tirta I.

\section{LITERATURE REVIEW}

Systems and Procedures. A system is a series of two or more components that are interrelated and interact with each other to achieve the goals (Romney and Steinbart 2014). A system is a group of two or more interrelated components that unite to achieve the same purposes (common purpose) (Hall 2014). "Procedure is a sequence of clerical work, usually involving several people in one or more parts, arranged to guarantee balance treatment of frequent company transactions" (Baridwan 2012). Whereas according to Mulyadi (2016) the procedure is a sequence of 'clerical' activities involving several people in one department or more, which is made to guarantee balance handling of a company transaction that occurs repeatedly. Based on the understanding of the procedures from the experts above, it concludes that the procedure is a sequence of 'clerical' activities involving several people in one or more parts designed to guarantee the balanced handling of repeated company transactions.

For example, a system provides a measurement of time, performance, information, and fundamental reason for producing goals. "If a system cannot fulfill its objectives, it must be repeated or routinely occur" (Mulyadi 2016).

Internal Control. Internal control is required in every company to regulate inside the company. Every company surely has internal problems, that is why internal control is needed. According to Mulyadi (2008), internal control systems include organizational structure, methods, and measures designed to manage wealth, to check the accuracy and reliability of accounting data, to support efficiency and to encourage compliance of management systems.

According to Mulyadi (2008) internal control has several objectives, such as:

- Maintaining organizational wealth;

- Checking the accuracy and reliability of accounting data;

- Encouraging operational efficiency;

- Encouraging compliance of management policies.

Internal control has elements that must be fulfilled to create an excellent internal control system within the company. According to Mulyadi (2008):

- An organizational structure that explicitly separates functional responsibility;

- The system of authority and recording procedures that provide adequate protection against wealth, debt, and income costs;

- Healthy practice in performing the duties and functions of each organizational unit;

- Employees whose quality is corresponding to their responsibilities.

\section{METHODS OF RESEARCH}

This study is descriptive research with the qualitative approach. The researcher conducted the study at Perum Jasa Tirta I located at Jalan Surabaya No. 2A, Sumbersari, Lowokwaru district, Malang Municipality, East Java, 65145. Data collection techniques used interviews and documentation with the researcher as the instrument and supported by interview and documentation guidelines. The research focuses are as follows:

- Procedure of submission for Working Advances and Working Advances accountability at Perum Jasa Tirta I Malang Head Office;

- The increase of internal control in the submission procedures and accountability for Working Advances at Perum Jasa Tirta. 


\section{RESULTS AND DISCUSSION}

Analysis of Submission Procedure and Working Advances Accountability in Perum Jasa Tirta I. The Submission Procedure and Working Advances Accountability at Perum Jasa Tirta I are going well because Perum Jasa Tirta had separated its functions based on the type of proposed Working Advances, namely Working Advances for routine activities and Working Advances for Operational \& Periodic activities. Perum Jasa Tirta I also separate its functions based on the suitability of Working Advances submission with RKOP \& PPUT. The separation of these functions will make it easier for the staff to check and inspect. Eventually, it will reduce errors and miscalculation in adjusting Working Advances with RKOP \& PPUT. However, there is still a deficiency in the approval stage for Working Advances performed by Director II. Considering the Director II often conducts External Service (DL), then the submission for Working Advances is frequently delayed and take much time. Bureau/Division/Unit must wait for payment of Working Advances a little longer since they have to wait for approval from Director II. It causes a delay in the implementation of the corporate operational activities. The researcher suggests a solution where the Director II always tries to carry out this procedure while at External Service (DL) activities. This can be done by sparing some free time in which Director II can return to the office to approve the Working Advances payment voucher. Other deficiencies are often due to the accumulation of accountability documents in the Working Advances verification stage of Management Accounting Division that may risk the documents for being loss and damage. The staff should verify the document gradually if it piles up with other jobs. Management Accounting Staff can also provide safer document storage to avoid document loss/damage during the delay time.

Analysis of Used Documents. The used documents shall contain all information identified from the entire transaction that occurs within the company. Documents used in Perum Jasa Tirta I must record the occurrence of the Working Advances submission and accountability transactions because this can provide information related to the functions if needed at any time. The documents used in Perum Jasa Tirta I are as follows:

- Quarterly Money Usage Program (PPUT);

- Letter of Planning Use of Funds Plan (RPU);

- Monthly Planning Use of Funds (RPUB);

- Payment Program on Outside Parties;

- Working Advances Payment Voucher;

- Checklist of Working Advances Verification Payment;

- Accountability Report of Working Advances;

- Checklist of Accountability Document Verification.

Based on the description above, the documents used in the submission and accountability for Working Advances are sufficiently completed and can help the staff to carry out submission procedure and Working Advances accountability. Bureau of General Affairs and Finance, especially the Budget Division of Perum Jasa Tirta I also save/archive the previous Working Advances documents because there are several procedures for submission and accountability for Working Advances that still require previous interrelated Working Advances documents.

Analysis of Used Records. The accounting used records by the Bureau of General Affairs and Finance of Jasa Tirta I have worked well and effective ddue to the existence of the recording of general journals and ledgers for recording all transactions of Perum Jasa Tirta I include submission and accountability for Working Advances. Nominal in general journals and ledger has been adjusted to the submission and accountability documents for Working Advances by the Financial Accounting Division and Management Accounting Division.

Analysis of Related Functions. The 'functions' or divisions in the company must perform their duties and obligations related to their job description. 'The functions' or divisions of Perum Jasa Tirta I will support the procedures of submission and accountability for a good Working Advances if they implement their duties accurately. The 'functions' 
related to the procedures for submission and accountability for the Working Advances of Perum Jasa Tirta I are as follows:

- The Receiver of Working Advances (Bureau/Division/Unit);

- Planning and Development Bureau (BPP);

- Bureau of General Affairs and Finance (BKU);

- Deputy of Engineering;

- Board of Directors.

Network Analysis Procedures that Form Submission procedure and Working Advances Accountability:

Procedure for Submission of the Quarterly Money Usage Program (PPUT). The procedures for submission of Quarterly Money Usage Program (PPUT) designed by the Bureau/Division/Unit are well implemented by directly submitting to the Board of Directors so that they can immediately monitor the proposed PPUT associated with the RKOP. Of course, it can reduce the misuse of excessive use of Working Advances and exceed the RKOP. The Bureau/Division/Unit also provides the duplicate of PPUT documents to the Bureau of General Affairs and Finance as a reference for each submission for Working Advances.

Submission Procedures for the Use of Funds Plan (RPU). The submission procedures for the Planning Use of Funds (RPU) has been carried out well considering the classification of Working Advances. It can reduce errors that occur during the submission process. The Working Advances Classification includes the Working Advances for Routine Activities and Periodic O\&P Activities (purchasing, self-management, etc.) and watershed protection/extension activities. Working Advances in Routine Activities is processed directly by the Budget Division. However, if the amount of the Working Advances does not correspond to the RKOP/PPUT, it will be submitted to the Planning \& Program Bureau (BPP) to get the recommendations. Whereas for the Working Advances in Periodic O\&M Activities (purchasing, self-management, etc.) and watershed protection/extension activities are handed over first to the Planning \& Program Bureau to get the recommendations. If the entire Working Advances submitted is correct then the Working Advances payment voucher will be produced immediately.

Procedures for making and approving payment vouchers. The procedures for making a Working Advances voucher has worked correctly. After the Working Advances perfectly adapted to the RKOP/PPUT, the Budget Division staff will produce The Working Advances voucher immediately. The approval procedures for voucher payment of Working Advances of Perum Jasa Tirta I has worked well since the differences in the parties in agreeing to the basis of the nominal of Working Advances.

In this procedure, there are also some deficiencies, such as the delay of approval from the Director II because the parties concerned often performing External Service (DL). Some may be worried that it will slow down the approval process for Working Advances vouchers and can hamper the operational work of Perum Jasa Tirta I. In this case, The Working Advances voucher that requires approval from the Director II is always depending on the relevant party to return to the Perum Jasa Tirta I office. Considering the Working Advances voucher must be immediately approved, the Director always takes the time to complete this procedure.

Payment Procedure for Working Advances. Working Advances Payment Procedure has implemented well with the payment system Using BNI Direct and CMS BRI systems. It, of course, can speed up the work of Working Advances payment transactions sent to the Bureaus/Divisions/Units whose presence are spread out in several areas of Indonesia.

The Procedure of Administration and Storing the Document of Working Advances Request. The procedure of administration and document of Working Advances request had been done well. It can be seen that the Financial Accounting Division that performed the administration directly on the same day as the day of the payment of Working Advances. Thereby, it can decrease the document accumulation that needs to be recorded and minimizes the mistake in recording the date in the journal and general ledger.

In addition, the procedure of storing the document of Working Advances request had also been done well by document storage according to the sequence number code of 
Working Advances voucher. It certainly facilitates the staff to find the document of the previous voucher of Working Advances since there is some new voucher of Working Advances that should be attached with the previous voucher of Advance Payment.

The Procedure in Composing the Progress Report of Working Advances. The procedure of composing the progress report of Working Advances had been performed well through seeing that each Bureau/Division/Unit composes it in two form i.e. physical file form and soft file form as the soft copy through SIAsSAP. It certainly makes the other functions easier to perform monitoring and inputting the data.

The Procedure of Monitoring the Rest of Working Advances and Tax Administration. The procedure of monitoring had been done well enough and on time since there was an obligation to submit the monitoring report every month to the Directors/Deputy/Corporate Secretary/SPI. It certainly can decrease document accumulation and it can minimize the possibility of lost or damaged document. The procedure of document verification by the Management accounting staff had not been done well since the Management accounting staff did not process the progress report of Working Advances document directly. It happened because the staff had to do other tasks. This makes the document accumulation happened and it engenders the possibility of lost or damaged document. Bearing in mind the importance of this document of Working Advances progress report, verification should be done gradually by the relevant staff in order to minimize the risk of lost or damaged document.

The Procedure of Administration and Document Storage. This procedure has been done well since the staff of Financial Accounting Division has done the administration for the document of Working Advances progress report and the document storage has been done by placing it in order according to the serial number of the document. It certainly can minimize the document accumulation and it makes the staff easier in searching the archived document when it is needed.

The Analysis of Internal Control in Perum Jasa Tirta I:

Organization Structure. Based on the research that has been done, the internal controls in Perum Jasa Tirta are:

- The function of making the voucher of Working Advances in Perum Jasa Tirta I had been done well since it is separated from the function of financial records. The document that had been made had been authorized by the relevant function according to the relevant provision. In addition, this function had been separated from the Payment Function of Working Advances that is performed by Cash Holder.

- In Perum Jasa Tirta I, the verification of the document of Working Advances progress report had been monitored by the staff of the management Accounting Division. This function is not separated from other functions in the Management Accounting Division. The staff of Management Accounting Division has verified the document of Working Advances progress report while doing other tasks. As consequence, the document accumulation of Working Advances progress report often happens, and it possibly causes lost or damaged document. Therefore, the researcher suggests performing the decentralization where the document verification will be done in each Division. Thereby, Profit and Loss Statement can be composed in each division.

All relevant functions had performed their tasks well during the procedure of Working Advances request and progress report. However, there were some weaknesses in presenting the hierarchy chart about organization structure. The organization structure presented by Perum Jasa Tirta I did not show the detail about the sub-division/bureau/unit. It can be seen from the flowchart that has been presented that some of the procedure executing division did not exist in the organization structure and there was no description about the job description.

Authorization System:

- The rectification of the nominal of Working Advances request is the right for the staff of Budget Division and it will be checked and authorized by the Head of Financial Bureau, BPP, and Directors according to the provision.

- The Working Advances that exceeds the limit (ceiling) RKOP/PPUT had been 
informed to the Office of Planning and Development (BPP) to get a recommendation and to be authorized by the Head of Financial Bureau, BPP, dan Directors according to the applicable policies.

- The agreement of Working Advances payment had been verified by the Budget Division Head and authorized by the Head of Financial Bureau, BPP, dan Directors based on the requirements. Nonetheless, it still has a weakness in authorizing the Working Advances payment done by the Directors. The relevant Director often goes External Service so the authorization system for the agreement of Working Advances payment can be obstructed and the operational performance of Perum Jasa Tirta I can also be obstructed. However, as long as the researcher did this research, the relevant Directors party always spare a time to authorize the Working Advances payment.

- The document of Working Advances Progress report that was relevant was not proceeded by the staff of the Management Accounting Division immediately. Nevertheless, the authorization had been done by the Head of Management Accounting Division and the Financial Bureau Head in accordance with the provision. The staff of the Management Accounting Division could not process this document immediately due to the accumulation of other tasks. Thereby, the authorization was also obstructed. Therefore, the researcher suggests that verification should be done gradually to avoid the document accumulation that can result in lost or damaged document.

Healthy Practices:

- The Working Advances for Regular Activities has been proposed to the Budget Division. The Working Advances for Periodic Operations \& Maintenance Program (handed over contractors, self-management, and etc.) and program of socialization/Watershed Conservation has been given to Office of Planning and Development (BPP)

- The Working Advances for Regular Activities that exceed the limit (ceiling) RKOP/PPUT has been given to the Office of Planning and Development (BPP) to be made a recommendation.

- Document for Working Advances request at Perum Jasa Tirta I, all the completeness, correctness, and validity of documents are always carefully checked by the Head of the Budget Department.

- Perum Jasa Tirta I have complied with the provisions in terms of Working Advances that exceed the limit of the RKOP/PPUT is signed by the relevant functions in accordance with its provisions. However, with the existence of directors and such relevant functions, authorization may be hampered because the directors frequently have External Service (Dinas Luar) which cause the procedure of Working Advances request become hampered as well. However, this obstacle is not very significant because this is the initial stage and when the directors have returned to the office, the authorization can be immediately carried out and processed.

- The process of approving the Working Advances Payment at Perum Jasa Tirta I will be given approval by the relevant functions in accordance with its provisions. The disadvantage of this stage is that the approval is related to the Directors. The stage of approval for Working Advances payment conducted by the directors may be hampered considering that these parties frequently have External Service (Dinas Luar). This is not a significant disadvantage because when the related directors have returned to the office, the procedures for approval of Working Advances payment can be immediately processed.

- Working Advances Payment at Perum Jasa Tirta I that has been approved is always immediately processed by the Cash Holder.

- The accountability report is in the form of soft copy data inputted by the Bureau/Division/Unit in the SIAsSAP program as the basis for inputting the data to the ASGI accounting program by Financial Accounting Department. Meanwhile, the hard 
copy version has been prepared as the basis for the UMK remaining balance by the Budget Department.

- The document of accountability report of Working Advances at Perum Jasa Tirta I which has been in accordance with the provision will be signed by the relevant functions in accordance with the requirements. However, there is a small disadvantage, that is the accumulation of verification of accountability report document for Working Advances payment because the Management Accounting Department staffs are busy with other more important work. The researcher can suggest gradual verification by Management Accounting staff to minimalize the risk of missing/damaged documents.

It can be said that there is a good procedure for Working Advances request and accountability report. However, there are some insignificant disadvantages in the procedures for Working Advances request and accountability report which is related to the Director II that often have External Service (Dinas Luar). Additionally, there is delayed verification of UMK accountability report documents because the Management Accounting Department staff have to do another work. However, it can be said that healthy practices have been implemented because all functions have complied with the procedural rules. This can improve the Perum Jasa Tirta I intern control regarding procedures for Working Advances request and accountability report.

Quality of Employees. All employees of Perum Jasa Tirta I have the responsibility in accordance with their respective authorities. The employees also have educational background suitable for their job at Perum Jasa Tirta I. Although the majority of employees at Perum Jasa Tirta I are High School/Vocational High School graduates, Perum Jasa Tirta I conducts an employee quality improvement which is performed through various activities such as outbound, seminars, training, etc. These employee quality improvements are not only intended for employees of High School/Vocational High School graduates only, but also aimed at employees of D3, S1, and S2 graduates.

\section{CONCLUSION}

The overall procedures for Working Advances request and accountability reports have run well and are conducted in accordance with the company regulations. However, there are some disadvantages in the process of approval of Working Advances payment voucher conducted by the Director II. This approval process is often delayed because the Director II frequently has External Service (Dinas Luar). Another disadvantage is in the verification stage of the accountability report document. There is often an accumulation of accountability reports that need to be verified by Management Accounting staff in this stage.

The overall intern control can be categorized as good, although there are disadvantages in the organizational structure chart presented by Perum Jasa Tirta I. Perum Jasa Tirta I do not present a detailed organizations structure and job descriptions. This is apparent from the functions in the Working Advances request and accountability procedures which are not listed in the organizational structure and description.

\section{SUGGESTIONS}

Adding new details about the hierarchical chart of organizational structure to show the position of sub-division/bureau/unit/section as stated in CHAPTER IV. This may ease the monitoring of each work in order to improve the intern control at Perum Jasa Tirta I. Adding explanation details in the job description at Perum Jasa Tirta I in accordance with those stated in CHAPTER IV. This may facilitate the auditor to see the position and job details of each division/sub-division/bureau/unit. 


\section{REFERENCES}

1. Baridwan, Z. (2012). Sistem Akuntansi Keuangan ( $5^{\text {th }}$ Ed). Yogyakarta: BPFE.

2. Hery. (2007). Siklus Akuntansi Perusahaan (1 ${ }^{\text {st }}$ Ed). Yogyakarta: Graha IImu.

3. Mulyadi. (2001). Sistem Akuntansi. Jakarta: Salemba Empat.

4. Mulyadi. (2016). Sistem Akuntansi ( $4^{\text {th }}$ Ed). Jakarta: Salemba Empat.

5. Ranatarisza, M. M., and Max, A. N. (2013). Sistem Informasi Akuntansi Pada Aplikasi Administrasi Bisnis. Malang: Universitas Brawijaya Press (UB Press).

6. Romney, M. B., and Paul. J. S. (2014). Sistem Informasi Akuntansi (13 ${ }^{\text {th }}$ Ed). Jakarta: Penerbit Salemba Empat.

7. Samryn, L. M. (2012). Pengantar Akuntansi. Jakarta: PT Raja Grafindo Persada.

8. Sumarsan, T. (2011). Akuntansi Dasar \& Aplikasi Dalam Bisnis. Yogyakarta: Sekolah Tinggi Ilmu Ekonomi.

9. Syah, H. (2010). Pengantar Umum Metodologi Penelitian Pendidikan Pendekatan Verivikatif. Pekanbaru: Suska Pres.

10. Yaumi, M., and Muljiono, D. (2014). Action Research: Teori, Model dan Aplikasinya. Jakarta: Kencana Prenadamedia Group. 